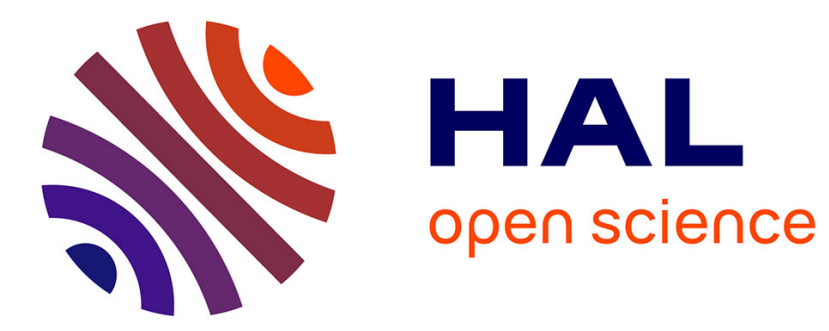

\title{
Impact of Commodity Price Volatility on External Debt: The Role of Exchange Rate Regimes
}

Joaquin Vespignani, Monoj Kumar Majumder, Mala Raghavan

\section{To cite this version:}

Joaquin Vespignani, Monoj Kumar Majumder, Mala Raghavan. Impact of Commodity Price Volatility on External Debt: The Role of Exchange Rate Regimes. 2021. hal-03106698

\section{HAL Id: hal-03106698 \\ https://hal.science/hal-03106698}

Preprint submitted on 12 Jan 2021

HAL is a multi-disciplinary open access archive for the deposit and dissemination of scientific research documents, whether they are published or not. The documents may come from teaching and research institutions in France or abroad, or from public or private research centers.
L'archive ouverte pluridisciplinaire HAL, est destinée au dépôt et à la diffusion de documents scientifiques de niveau recherche, publiés ou non, émanant des établissements d'enseignement et de recherche français ou étrangers, des laboratoires publics ou privés. 


\title{
Impact of Commodity Price Volatility on External Debt: The Role of Exchange Rate Regimes
}

\author{
Monoj Kumar Majumder ${ }^{\text {a,d }}$, Mala Raghavan ${ }^{\text {a,b }}$, Joaquin Vespignani ${ }^{\text {a,b }}$ \\ ${ }^{\text {a }}$ Tasmanian School of Business and Economics, University of Tasmania, Australia \\ ${ }^{c}$ Centre for Applied Macroeconomic Analysis, Australian National University, Australia \\ ${ }^{\mathrm{d}}$ Department of Agricultural Economics, Sher-e-Bangla Agricultural University, Bangladesh
}

\begin{abstract}
This study explores the impact of commodity price volatility on external debt accumulation under fixed, managed, and floating regimes. We estimate dynamic panel data models for 97 countries from 1993 to 2016. Our empirical findings show that commodity price volatility increases external debt accumulation for commodity-exporting countries. This impact is three-times higher for countries with fixed exchange rate regimes compared to managed floating exchange rate regimes. Under floating exchange regimes, the effect of commodity price volatility on external debt is statistically insignificant. Our results suggest that the adoption of a floating exchange rate regime by commodity-exporting countries is critical to mitigate the effects of commodity price volatility on external debt accumulation.
\end{abstract}

Keywords: Commodity price volatility, external debt, commodity-exporting countries, exchange rate regime

JEL classification: E62, F31, F34, G01

Corresponding authors.

E-mail addresses: monojkumar.majumder@utas.edu.au (M. K. Majumder) mala.raghavan@utas.edu.au (M. Raghavan), Joaquin.vespignani@utas.edu.au (J. Vespignani)

\section{Introduction}

The global financial crisis (GFC) and the present Covid-19 pandemic have forced many governments to stimulate the economy by increasing fiscal deficits. Consequently, external debt as a percentage of GDP has significantly increased for many countries in the last decade. 
Recent data from the International Monetary Fund (IMF) show that for emerging markets and developing economies, general government gross debt as a percentage of GDP increased from $77.9 \%$ in 2008 to $124.1 \%$ in 2020 , while for advanced economies, it increased from $38.6 \%$ to $61.4 \%$ for the same two periods. This observation is particularly important for commodity-abundant economies. In this study, we explore the impact of commodity price volatility on external debt for 97 countries in a panel dataset for the period 1993 to 2016 . Further, we examine the role of alternative exchange rate regimes in influencing the impact of commodity price volatility on external debt accumulation for both commodity-exporters and commodity-importers.

Commodity price shocks can create a dilemma for countries, if fiscal revenue largely depends on commodities. The risk being that revenue boosted by high commodity prices in good times translate into long-lasting expenditure increasing external debt. For example, Algeria, Nigeria, and Venezuela fell prey to over-optimistic spending habits during the 1970s commodity price booms. These countries use current and expected revenues to finance different development projects (Brown, Crawford and Gibson 2008). Such projects became unsustainable when commodity prices declined, and volatility increased during the GFC and the Covid-19 pandemic. As the fiscal deficit rises, governments borrow money from international financial markets, which increases the country's debt levels (Brown and Gibson 2006). In general, borrowing money helps to increase economic growth by reducing the gap between domestic saving and investment. However, external debt sustainability may deteriorate if the debt to GDP ratio becomes too large. Consequently, governments face a decreased capacity to make debt repayments, and the probability of defaulting increases (Pattillo, Poirson and Ricci 2002).

Commodity prices are by nature more volatile than the prices of manufactured goods [see e.g., Dossani and Elder (2020) Radetzki and Wårell (2016), Jacks, O’Rourke and 
Williamson (2011) and Szirmai (2005)], making export revenue highly volatile, especially for commodity-exporting countries. ${ }^{1}$ In this study, we select commodity-exporting countries following Cavalcanti, Mohaddes, and Raissi (2012), who classified countries as commodity exporters if the primary commodity constitutes more than 50 per cent of the country's total exports.

Further, this study examines the role of different exchange rate regimes in absorbing external shocks to the economies. We hypothesize that a fixed exchange rate regime magnifies the commodity price shocks, which became obvious after the Argentine currency and debt crisis in 2001-2002 (Edwards and Yeyati 2005). Under the fixed exchange rate system, economic stability is delayed, awaiting adjustment of nominal wages, commodity prices, or an increase in volatility of output and employment. ${ }^{2}$ As a result, it is assumed that commodity price volatility increases external debt under a fixed exchange rate regime. In contrast, a floating exchange rate regime may support the economic stability of a country by responding to commodity price shocks through exchange rate adjustments. In this study, we include a further classification, i.e. managed floating exchange rate regimes, where currencies can move within predetermined limits. The different classification of exchange rate regimes are obtained from Reinhart, Ilzetzki and Rogoff (2009).

There is considerable literature on the relationship between the macroeconomy and commodity price volatility, but lack of information about commodity price volatility and external debt. This study aims to undertake an empirical analysis of the relationship between commodity price volatility and external debt along with the commodity price changes by exploring the following research questions: How does commodity price volatility affect

\footnotetext{
1 Jacks, O'Rourke and Williamson (2011) show that since 1960, Latin American, South Asian, and African primary commodity exporting countries face three times higher volatility in the terms of trade than manufacturing-exporting industrial economies.

${ }^{2}$ Under a fixed exchange rate regime, the domestic currency is fixed to another currency or a basket of currencies. Whereas under a floating exchange rate regime, the nominal exchange rate is allowed to move freely in response to supply and demand conditions in the foreign exchange market.
} 
external debt accumulation? Are these effects different for commodity-exporting and commodity-importing countries? Does the exchange rate regime matter for government debt accumulation?

This study fills the gap on two strands of the existing literature. First, the study is linked to the literature on the nexus between commodity prices and external debt, which generally shows a negative relationship for commodity-exporting countries [see e.g., Swaray (2005), Hausmann and Gavin (1995), and Olukoshi (1989)]. ${ }^{3}$ Second, the study is related to the literature on exchange rate regimes. The argument favours the floating exchange rate regimes established by Friedman (1953) and Mundell (1961), which state that floating exchange rates can better absorb external shocks than fixed exchange rates. The reason being floating exchange rates allow faster adjustment of relative prices and quantities. Dąbrowski and Wroblewska (2016), Hoffmann (2007), Edwards and Yeyati (2005), Ghosh et al. (1997), Flood and Rose (1995), and Baxter and Stockman (1989) empirically find that floating exchange rates can absorb external shocks faster than fixed exchange rates. In contrast, Masson, Goldstein and Frenkel (1991), Aghevli, Khan and Montiel (1991) and Giavazzi and Pagano (1988) argue that a fixed exchange rate provides more fiscal discipline in light of the lax fiscal policies in developing countries.

We first estimate the impact of commodity price volatility on fiscal balance for all 97 countries (see Table A1 for the list of countries included in this study). These countries are then divided into two subgroups - commodity-exporting and commodity-importing countries to examine how the impact of commodity price volatility differs according to the level of commodity endowments (see Table A2).

\footnotetext{
${ }^{3}$ In this study, we explore the impact of commodity price volatility on external debt along with commodity price changes.
} 
The results of this study are novel, showing that there is a positive relationship between commodity price volatility and external debt: external debt increases with commodity price volatility in the full sample and for the commodity-exporting countries. We do not find any statistically significant impact of commodity price volatility on external debt in commodity-importing countries. Further, our empirical results show that commodity price volatility has no statistically significant impact on external debt in countries that operate under floating exchange rate regimes.

The paper proceeds as follows. Section 2 reviews the literature. In Section 3, we describe the movements in commodity price volatility and external debt. In Section 4, we present the theory of the nexus between external shocks and exchange rate regimes. The methodology of this study is described in Section 5. We then describe the data and variables in Section 6 and Section 7 presents the empirical results from panel data estimation. Finally, Section 8 provides a conclusion and offers directions for future study.

\section{Literature review}

Lopez-Martin, Leal and Fritscher (2017), Arezki and Brückner (2012), Kamola (2007), Swaray (2005), among others, find a negative relationship between commodity price changes and government external debt, indicating that external debt decreases with increased commodity prices and vice-versa. The government can repay a portion of its debt with the extra revenue accrued from the commodity windfalls. Conversely, Nooruddin (2008) finds that government debt burden increases with commodity price booms. This is due to the increase in government expenditure designed to expand infrastructure and improve noncommodity productive capacity. 
Another reason is that rapid commodity price increases encourage corrupt and rentseeking behaviour and exacerbate societal tensions when the distribution of commodity revenues is not considered equitable (Ndikumana \& Boyce 2000, and Ajayi 1991). ${ }^{4}$ Further, the higher volatility in revenues reduces the time horizons of policy actors who feel compelled to spend revenues when they are available. Overall, these various effects of revenue volatility result in rising fiscal deficits, the financing for which governments obtain through external borrowing (Edo 2002). These studies only focused on the impact of commodity price on external debt and no attention was given to commodity price volatility.

Some of the current literature documents the reaction of public debt positions to the output cycle rather than in direct response to commodity price cycles (i.e., only indirectly linking commodity price fluctuations with external debt accumulation), linking the impact of commodity prices only through their possible effect on GDP. According to Giles and Paret (2018), Bittencourt (2015), Forslund, Lima and Panizza (2011), and Barro (1979) there is a countercyclical relationship between output cycles and public debt, indicating that public debt decreases with the rise of national income. However, these studies do not focus on the direct impact of commodity price cycles on government debt policy. While the effect of commodity prices on government external debt policies has been studied in the literature, there is a lack of analysis of the impact of commodity price volatility on government debt policies.

\section{Commodity price volatility and external debt}

In this section, we discuss the movement of commodity price volatility and external debt over time. In Figure 1, the primary axis, left-hand side (LHS), represents the value of average external debt as a percentage of GNI for all 97 countries in the sample, commodity-exporters,

\footnotetext{
${ }^{4}$ In public choice theory and economics, rent-seeking involves aiming to increase one's share of existing wealth without creating new wealth. Rent-seeking results in reduced economic efficiency through poor allocation of resources, reduced actual wealth-creation and lost government revenue.
} 
and commodity-importing countries. On the secondary axis, right-hand side (RHS), we present the measure of commodity price volatility. From the Figure 1, it is observed that from the early-1990s to the mid-2000s, commodity price volatility was low, reflecting the period referred to as the 'Great Moderation'. 'In 2007-2009 (i.e., during the GFC), a big spike was observed in commodity price volatility. The period after 2009 shows greater volatility than the pre-GFC periods.

The LHS of Figure 1 presents the trend of external debt for the three-country groups, all of which have a similar trend, though the external debt is higher in commodity-exporting countries. ${ }^{6}$ We also observe that during the 1980 s, external debt increased continuously. The period of high debt in the 1980s is known as the 'Washinton Consensus': countries were under pressure to implement major policy reforms, such as opening their economies to increased trade, privatizing state-owned firms, and seeking foreign investment. The reforms were often imposed on developing countries as a condition for debt relief and financial support from Washington DC-based institutions, namely, the United States Treasury, the IMF, and the WB.

A striking feature of Figure 1 shows that during the Great Moderation period (low commodity price volatility), the external debt declines substantially, particularly in commodity-exporting countries. After 2008, commodity price volatility increases in line with external debt increases.

\footnotetext{
${ }^{5}$ The term 'Great Moderation' refers to a reduction in the volatility of business cycle fluctuations starting in the mid-1980s. Bernanke (2004) hypothesise three potential causes for this economic stability: structural change in the economy, improved economic policy and good luck.

${ }^{6} \mathrm{We}$ use the average of external debt data in Figure 1.
} 


\section{Theoretical background}

The impact of external shocks under different exchange rate regimes can be analysed by the movement of investment-savings (IS) curves that describe how the goods and money markets interact to balance the economy's interest rate and output. In this section, we explain a possible channel in which the impact of commodity price volatility affects external debt using the standard IS curve under a fixed exchange rate and floating exchange rate regimes.

\subsection{Commodity price volatility shocks in commodity-exporting countries under the floating and fixed exchange rate regimes}

Figure 2a shows the effects of commodity price volatility under a floating exchange rate regime. Starting from the initial equilibrium at point $A$, where the initial output is $\mathrm{Y}_{0}$. Commodity price volatility decreases investment due to macroeconomic uncertainty. ${ }^{7}$ As a result, the initial $\mathrm{IS}_{0}$ curve shifts to the left $\left(\mathrm{IS}_{2}\right)$. The new equilibrium point is $\mathrm{B}$, where the output is $\mathrm{Y}_{1}$, which is lower than the previous output level at point $\mathrm{A}\left(\mathrm{Y}_{0}\right)$. At point $\mathrm{B}$, the interest rate falls below the world interest rate, causing capital outflow, leading to the depreciation of the currency under the floating exchange rate regime. As the currency depreciates, export expands and import falls, causing output to rise again and the IS curve shifts towards its new equilibrium point at $\mathrm{C}$. Therefore, floating exchange rate helps to stabilise the economy leading to higher outputs and eventually improve the fiscal position due to the automatic fiscal stabilizer.

Figure $2 \mathrm{~b}$ shows the effects of commodity price volatility in the economy under $a$ fixed exchange rate regime. The initial equilibrium point is A, where the country's equilibrium output is $\mathrm{Y}_{0}$. The commodity price volatility causes decrease in investment and output in commodity-exporting countries due rising uncertainty. Therefore, the $\mathrm{IS}_{0}$ curve

\footnotetext{
${ }^{7}$ Note that commodity price volatility in a commodity exporting country may lead to uncertainty for investors in all sectors related to commodities.
} 
shifts to the left as $\mathrm{IS}_{1}$. The new equilibrium point is $\mathrm{B}$, where the output is $\mathrm{Y}_{1}$, which is lower than the previous equilibrium point $\mathrm{A}\left(\mathrm{Y}_{0}\right)$. Under the fixed exchange rate regime, the central bank is forced to purchase the domestic currency to keep its value of the currency unchanged. As a result, the domestic money supply decreases. This monetary contraction results in a further decrease in output. Figures $2 \mathrm{a}$ and $2 \mathrm{~b}$ explain why commodity price volatility increases external debt more under a fixed exchange rate regime compared to floating exchange rate regime. In Figure 3, we show the flowchart of this theoretical explanation.

\section{Methodology}

To explore the impact of commodity price volatility on external debt, we estimate Equation 1 using the following dynamic panel data estimation models: (i) pooled ordinary least square (pooled OLS); (ii) fixed-effect (FE), and (iii) random effect (RE) models, which are commonly used in the literature. To select the appropriate model, we use the Hausman test. The Hausman test, favour the FE model as our baseline model and thus it is described in this section. Results for the Hausman test are presented in Table A 6 in Appendix A.

\subsection{The benchmark model}

Our benchmark model captures all effects that are specific to a country and that they do not vary over time (fixed effect), meaning that the model controls for unobserved heterogeneity when it remains constant over time and is correlated with all dependent and independent variables. We estimate the following model:

$$
\begin{array}{rr}
P C E D_{i, t}=\beta_{0 i}+\beta_{1} P C E D_{i, t-1}+\beta_{2} C P V_{i, t}+\beta_{3} P C C P_{i, t}+\beta_{4} R I R_{i, t}+\beta_{5} F D I_{i, t}+\beta_{6} C A B_{i, t} \\
+ & \beta_{7} G D P_{i, t}+\varepsilon_{i, t}
\end{array}
$$


where $\beta_{0 i}$ is the unobserved time-invariant individual effect. $P C E D_{i, t}$ is the percentage change in external debt as percentage of gross national income $(\mathrm{GNI}) ; P C E D_{i, t-1}$ represents the lag of the independent variable; $C P V_{i, t}$ indicates the commodity price volatility, while $P C C P_{i, t}$ represents the percentage change in commodity prices. $R I R_{i, t}, F D I_{i, t}$, $C A B_{i, t}$ and $G D P_{i, t}$ represent the real interest rate (annual \%), foreign direct investment (\% of GDP), current account balance (\% of GDP), and GDP per capita growth (annual \%) respectively. A detailed description of the variables is presented in Table A3 in Appendix A.

The subscripts $i$ and $t$ denote the specific country and period, respectively. The idiosyncratic disturbance term is denoted by $\varepsilon_{i, t}$.

\section{Data and description of the variables}

\subsection{The data}

This study employs an unbalanced panel data dataset for 97 . The frequency of the data is annual, covering the period from 1993 to 2016. The countries and periods included are based on data availability. The data for external debt, foreign direct investment, real interest rate, current account balance, and GDP per capita growth are collected from the World Development Indicators (WDI) of the WB.

The data for commodity prices is from the IMF primary commodity price sheet. We convert the data into the annual form by taking the average of monthly data. Commodity prices are expressed as an index using the year 2005 as a base price. We estimate commodity price volatility from the commodity price index using the standard deviation from monthly data to capture monthly price variation. Formally, we estimate commodity price volatility as:

$$
\sigma_{t}=\sqrt{\sum_{\tau=1}^{12} \frac{\left(P_{\tau}-\mu_{t}\right)^{2}}{12-1}}
$$


where, $\sigma_{\mathrm{t}}=$ commodity prices volatility at time $t, P_{\tau}=$ commodity monthly prices, $\mu_{\mathrm{t}}=$ average price $\left(\mu_{t}=(1 / 12) \sum_{\tau=1}^{12} P_{\tau}\right)$, and $\tau=$ months $(1,2,3 \ldots 12)$

\subsection{Descriptive statistics, unit root test, and Hausman test}

Table A4 presents descriptive statistics. There is a significant difference between the maximum and minimum values of the commodity price volatility i.e. 36.65 and 0.91 , respectively. The standard deviation of commodity price volatility is 7.8 indicating that there is a large dispersion from its mean value (8.50).

In Table A5, we use the Augmented Ducky-Fuller (ADF) and the Phillips-Perron (PP) tests to evaluate the stationary properties of all variables. Except for external debt and commodity prices, all variables included in the model are stationary. The $\rho$-values of external debt and commodity prices are $>0.05$, indicating that these two series are not stationary. To make these series stationary, we use the percentage change of these two series.

Table A6 shows that the $p$-value of the Hausman test is less than $5 \%$, indicating that we can reject the null hypothesis and accept the alternative hypothesis that the FE model is appropriate, this result is consistent for all three country groups.

\section{Empirical results}

In this section, we describe the estimated coefficients for all countries in the sample, and those of commodity-exporting and commodity-importing countries estimated with the FE model. The result of the Hausman test indicates that the FE model is the most appropriate choice for this study. ${ }^{8}$ In the sub-section 7.1 , we discuss results for different country groups (full sample, commodity-exporting, and commodity-importing countries) reported in Tables 1 and 2, and in sub-section 7.2. we discuss results for different country groups with alternative

\footnotetext{
${ }^{8}$ Description of pooled OLS and RE are presented in Appendix B.
} 
exchange rate regimes reported in Tables 3, 4 and 5. Finally, in sub-section 7.3 we discuss results for the robustness analysis reported in Table 6 .

\subsection{Results for different country groups (full sample, commodity-exporting, and commodity-importing countries)}

Table 1 shows the results for the 97 countries (full sample). Columns 1, 2, and 3 estimates the pooled OLS, FE, and RE regression models, respectively. ${ }^{9}$ The coefficient of the commodity price volatility is positive $(0.17$, see column 2$)$, indicating that change in external debt increases with commodity price volatility in all countries in the sample. All things being equal, a one standard deviation increase in commodity price volatility, leads to a 0.17 unit growth in external debt as a percentage of GNI. The negative coefficient of commodity price changes $(-0.24$, see column 2$)$ indicates that growth in external debt falls with the increase in commodity prices. A one-unit increase in commodity prices is associated with a significant decrease in the change in external debt by 0.24 units. The results are consistent across all three-panel data estimation models and are statistically significant at the $1 \%$ level.

Table 2 shows the effects of commodity price volatility in the growth of external debt in commodity-exporting and commodity-importing countries. The coefficient of the commodity price volatility is positive (0.32) for commodity-exporting countries' (higher than the full sample) meaning that commodity price volatility has a larger effect on commodity exporters' external debt accumulation (see column 2 in Table 2). This is likely because in commodity-exporting countries, commodity-linked fiscal revenues constitute a significant share of the government's revenues. Conversely, commodity price volatility does not show any statistically significant impact on external debt in commodity-importing countries (see columns 4, 5, and 6). Our result is consistent with the view of Cavalcanti, Mohaddes and

\footnotetext{
${ }^{9}$ Note that to conserve space in this section, we only discuss the coefficient of the variables of interest: commodity price volatility and commodity price changes. The coefficients of other control variables are consistent with the literature.
} 
Raissi (2012) that commodity-importing countries have highly diversified commodity export and import baskets. Thus, these countries are not fully dependent on commodity revenues, and volatility in commodity prices has less or no effect on those countries compared to commodity-exporting countries.

Table 2 also shows a negative nexus between change in commodity prices and growth in external debt, indicating that external debt accumulation significantly decreases with increases in commodity prices in commodity-exporting countries (see columns 1,2 , and 3 ). Such evidence suggests that exporting countries may repay their external loans by windfall revenues from commodity price booms. This result is supported by Swaray (2005), who finds a negative relationship between government debt and commodity prices in exporting countries.

Our empirical results also show that external debt decreases with the increase in commodity prices in commodity-importing countries. One of the plausible reasons for this negative link between commodity price changes and external debt is, importing countries collect revenue by imposing taxes on imported commodities. For example, in the Organisation for Economic Co-operation and Development (OECD) countries, the average oil import tax is $51.3 \%$ per litre.

\subsection{Results for different country groups with alternative exchange rate regimes}

In this section, we discuss the impact of commodity price volatility on external debt with alternative exchange rate regimes, in line with the theoretical framework described in Section 4. In Table 3, we present the empirical results for the full sample, and we observe that the coefficient of commodity price volatility is statistically significant in both fixed exchange rate (column 1) and managed floating exchange rate regimes (column 2) though the impact is higher in the case of fixed regime (0.34) compared to the managed floating regime $(0.32)$. 
However, we do not find any statistically significant impact of commodity price volatility on external debt under a floating exchange rate regime. These empirical findings are consistent with the framework described in Section 4.

Table 4 shows the results for the impact of commodity price volatility on external debt in commodity-exporting countries under three different exchange rate regimes. The coefficient of commodity price volatility is higher than the full sample (see Table 3) under both the fixed and managed floating exchange rate regimes, indicating that commodityexporting countries are more sensitive to commodity price volatility under both regimes. Table 4 also shows that the coefficient of commodity price volatility is three times higher in a fixed exchange rate regime (1.21) compared with a managed floating exchange rate regime (0.37), while the results are statistically insignificant under a floating exchange rate regime.

In Table 5, we present the role of alternative exchange rate regimes to examine the impact of commodity price volatility on external debt in commodity-importing countries. The empirical results show that commodity price volatility impact on external debt increases in the managed floating exchange rate regime. However, we do not find any statistically significant impact under a floating exchange rate regime or the fixed exchange rate regime.

\subsection{Robustness analysis}

In this section, we use the one-step system of General Method of Moments (system-GMM) estimator of Arellano and Bond (1991) and Blundell and Bond (1998) in the estimation that addresses the possible endogeneity problem in the model. Table 6 shows the results of the estimation of Equation (1) using a one-step system GMM. Results show that the coefficients of commodity price volatility are $0.17,0.34$ and 0.06 in the full sample, commodity-exporting and commodity-importing countries, respectively which are similar with our baseline model. 
The coefficients of other variables are not significantly altered by the one-step system GMM model from the findings estimated by the benchmark FE model.

\section{Conclusion}

This study aimed to explore the impact of commodity price volatility on external debt. Using dynamic panel data models for 97 countries for the period from 1993 to 2016, we found that external debt increases with commodity price volatility. Our empirical findings show that commodity price volatility has a significant adverse effect on external debt in the full sample and for commodity-exporting countries. However, we do not find any statistically significant impact on commodity-importing countries.

This study also examines the impact of commodity price volatility in three different exchange rate regimes: fixed, managed floating, and freely floating. Once the exchange rate is freely determined by the market (floating exchange rate), the impact of commodity price volatility on external debt is statistically insignificant. When the exchange rate is completely fixed, compared to a managed floating exchange rate, the impact is three times higher in commodity-exporting countries. These results have important monetary policy implications, as our results indicate that the adoption of a floating exchange rate regime is critical to reduce the adverse impact of commodity price volatility on external debt, especially for commodityexporting countries. 


\section{Reference}

Aghevli, BB, Khan, MS \& Montiel, P 1991, Exchange rate policy in developing countries: some analytical issues, International Monetary Fund, Washington, DC.

Ajayi, SI 1991, Macroeconomic approach to external debt. The case of Nigeria.

Arellano, M., Bond, S., 1991, 'Some tests of specification for panel data: monte carlo evidence and an application to employment equations' Review of Economic Studies 58, 277297.

Arezki, R \& Brückner, M 2012, 'Commodity windfalls, democracy and external debt', The Economic Journal, vol. 122, pp. 848-866.

Barro, RJ 1979, 'On the determination of the public debt', Journal of Political Economy, vol. 87, pp. 940-971.

Baxter, M \& Stockman, AC 1989, 'Business cycles and the exchange-rate regime: some international evidence', Journal of Monetary Economics, vol. 23, pp. 377-400.

Bernanke, B 2004, The great moderation, speech given at the Meeting of the Eastern Economic Association, 20 February, 2004, Washington, DC.

Bittencourt, M. 2015. 'Determinants of government and external debt: Evidence from the young democracies of South America', Emerging Markets Finance and Trade, vol. 51, pp. $463-472$.

Blundell, R \& Bond, S., 1998, 'Initial conditions and moment restrictions in dynamic paneldata models' Journal of Econometrics 87, 115-143.

Borensztein, E, De Gregorio, J \& Lee, J 1998, 'How does foreign direct investment affect economic growth?', Journal of International Economics, vol. 45, pp. 115-135.

Brown, O., Crawford, A. \& Gibson, J. 2008. Boom or bust. How commodity price volatility impedes poverty reduction, and what to do about it.

Brown, O. \& Gibson, J. 2006. Boom or Bust: Developing Countries' rough ride on the commodity price rollercoaster.

Cavalcantia, T. V. D. V., Mohaddesab, K. \& Raissic, M. 2012. Commodity Price Volatility and the Sources of Growth.

Céspedes, LF \& Velasco, A 2014, 'Was this time different?: Fiscal policy in commodity republics', Journal of Development Economics, vol. 106, pp. 92-106.

Crowley, S 2007, 'Likelihood-based inference in co-integrated vector autoregressive models', International Studies of Management and Organization, vol. 9, pp. 113-133.

Dąbrowski, MA \& Wroblewska, J 2016, 'Exchange rate as a shock absorber in Poland and Slovakia: Evidence from Bayesian SVAR models with common serial correlation', Economic Modelling, vol. 58, pp. 249-262.

Dossani, A, \& Elder, J. 2020 'Uncertainty and energy extraction.' Applied Economics vol. 52, pp 6031-6044.

Dufrénot, G, \& Paret, AC. (2018) 'Sovereign debt in emerging market countries: not all of them are serial defaulters.' Applied Economics vol. 50, pp. 6406-6443.

Edo, SE 2002, 'The external debt problem in Africa: A comparative study of Nigeria and Morocco', African Development Review, vol. 14, pp. 221-236. 
Edwards, S \& Yeyati, EL 2005, 'Flexible exchange rates as shock absorbers', European Economic Review, vol. 49, pp. 2079-2105.

Flood, RP \& Rose, AK 1995, 'Fixing exchange rates a virtual quest for fundamentals', Journal of Monetary Economics, vol. 36, pp. 3-37.

Forslund, K, Lima, L \& Panizza, U 2011, 'The determinants of the composition of public debt in developing and emerging market countries', Review of Development Finance, vol. 1, pp. 207-222.

Friedman, M 1953, 'The Case for Flexible Exchange Rates', in Essays in Positive Economics, University of Chicago Press, Chicago, pp. 157-203.

Ghosh, AR, Gulde, A-M, Ostry, JD \& Wolf, HC 1997, 'Does the nominal exchange rate regime matter?' NBER Working Papers 5874, National Bureau of Economic Research, Inc.

Giavazzi, F \& Pagano, M 1988, 'The advantage of tying one's hands: EMS discipline and central bank credibility', European Economic Review, vol. 32, pp. 1055-1075.

Jacks, DS, O'Rourke, KH \& Williamson, JG 2011, 'Commodity price volatility and world market integration since 1700', Review of Economics and Statistics, vol. 93, pp. 800--813.

Hausmann, R \& Gavin, M 1995, 'Overcoming Volatility in Latin America', Office of the Chief Economist, Washington, DC: Inter-American Development Bank, August.

Hoffmann, M 2007, 'Fixed versus flexible exchange rates: Evidence from developing countries', Economica, vol. 74, pp. 425-449.

Hsiao, C 2014, Analysis of panel data, Cambridge University Press, Cambridge, UK.

International Monetary Fund 2018, Commodity data portal, viewed 2018 <https://www.imf.org/en/Research/commodity-prices $>$.

Kalou, S and Paleologou, SM 2012, 'The twin deficit hypothesis: revisiting an EMU country', Journal of policy modelling, vol.34, pp.230-241.

Kamola, IA 2007, 'The global coffee economy and the production of genocide in Rwanda', Third World Quarterly, vol. 28, pp. 571-592.

Lopez-Martin, B, Leal, J \& Fritscher, AM 2017, 'Commodity price risk management and fiscal policy in a sovereign default model', Journal of International Money and Finance.

Masson, PR, Goldstein, M \& Frenkel, JA 1991, 'Characteristics of a successful exchange rate system', in Occasional Paper No. 82, International Monetary Fund, Washington, DC.

Medina, L 2010. The dynamic effects of commodity prices on fiscal performance in Latin America.

Mehta, M \& Kayumi, HF 2014, 'Effect of India's current account deficit on external debts and foreign exchange rates', IOSR Journal of Economics and Finance, pp. 54-65.

Mohanty, R.K. 2018, 'An empirical investigation of twin deficits hypothesis: evidence from India', Journal of Quantitative Economics, vol. 17, pp.579-601.

Mundell, RA 1961, 'A theory of optimum currency areas', The American Economic Review, vol, 51, pp. 657-665.

Ndikumana, L \& Boyce, J 2000, 'Is Africa a Net Creditor? New Estimates of Capital Flight from Severely Indebted Sub-Saharan African Countries, 1970-1996', PERI Working Paper No. 5 . 
Nooruddin, I 2008, 'The political economy of national debt burdens, 1970-2000', International Interactions, vol. 34, pp. 156-185.

Olukoshi, AO 1989, 'The origins, nature and dimensions of the African debt crisis', The African Debt Crisis, Nigerian Institute of International Affairs, Nigeria.

Omojolaibi, JA \& Egwaikhide, FO 2014, 'Oil price volatility, fiscal policy and economic growth: a panel vector autoregressive (PVAR) analysis of some selected oil-exporting African countries', OPEC Energy Review, vol. 38, pp. 127-148.

Pattillo, CA, Poirson, H \& Ricci, LA 2002, External debt and growth, International Monetary Fund, Washington, DC.

Radetzki, M \& Wårell, L 2016, A handbook of primary commodities in the global economy, Cambridge University Press, Cambridge.

Reinhart, CM, Ilzetzki, EO \& Rogoff, KS 2009, Exchange rate arrangements entering the 21st century: which anchor will hold.

Roubini, N \& Sachs, JD 1989, 'Political and economic determinants of budget deficits in the industrial democracies', European Economic Review, vol. 33, pp. 903-933.

Spatafora, N \& Samake, I 2012, Commodity price shocks and fiscal outcomes.

Szirmai, A 2005, The dynamics of socio-economic development, Cambridge University Press Cambridge.

Swaray, RB 2005, Primary Commodity Dependence and Debt Problem in Less Developed Countries.

Waheed, A 2017, 'Determinants of External Debt: A Panel Data Analysis for Oil \& Gas Exporting and Importing Countries', International Journal of Economics and Financial Issues, vol. 7, no. 1, pp. 234-240.

World Bank 2018, World Development Indicators, viewed February 2018, < https://data.worldbank.org/indicator/NY.GDP.MKTP.KD>. 
Table 1: Determinants of the external debt (full sample)

\begin{tabular}{|c|c|c|c|}
\hline & \multicolumn{3}{|c|}{ Dependent variable: $P C E D_{i, t}$} \\
\hline & $\begin{array}{c}\text { pooled OLS } \\
\text { (1) }\end{array}$ & $\begin{array}{l}\text { FE } \\
(2)\end{array}$ & $\begin{array}{l}\mathrm{RE} \\
(3)\end{array}$ \\
\hline \multirow{3}{*}{$P C E D_{i, \mathrm{t}-1}$} & $0.09^{* * *}$ & $0.03 * * *$ & $0.09 * * *$ \\
\hline & $(0.01)$ & $(0.01)$ & $(0.01)$ \\
\hline & {$[0.02]$} & {$[0.02]$} & {$[0.02]$} \\
\hline \multirow[t]{3}{*}{$C P V_{i, t}$} & $0.16^{* *}$ & $0.17 * *$ & $0.16^{* *}$ \\
\hline & $(0.07)$ & $(0.07)$ & $(0.07)$ \\
\hline & {$[0.09]$} & {$[0.10]$} & {$[0.09]$} \\
\hline \multirow[t]{3}{*}{$P C C P_{i, t}$} & $-0.28 * * *$ & $-0.24 * * *$ & $-0.28 * * *$ \\
\hline & $(0.03)$ & $(0.03)$ & $(0.03)$ \\
\hline & {$[0.03]$} & {$[0.03]$} & {$[0.03]$} \\
\hline \multirow{3}{*}{$R I R_{i, t}$} & $0.18 * * *$ & $0.25 * * *$ & $0.18 * * *$ \\
\hline & $(0.05)$ & $(0.06)$ & $(0.05)$ \\
\hline & {$[0.08]$} & [0.09] & {$[0.08]$} \\
\hline \multirow{3}{*}{$F D I_{i, t}$} & 0.05 & -0.02 & 0.05 \\
\hline & $(0.11)$ & $(0.14)$ & $(0.11)$ \\
\hline & {$[0.14]$} & {$[0.16]$} & {$[0.14]$} \\
\hline \multirow[t]{3}{*}{$C A B_{i, t}$} & $-0.12 *$ & $-0.50 * * *$ & $-0.12 *$ \\
\hline & $(0.07)$ & $(0.09)$ & $(0.07)$ \\
\hline & {$[0.14]$} & {$[0.16]$} & {$[0.14]$} \\
\hline \multirow[t]{3}{*}{$G D P_{i, t}$} & $-1.04 * * *$ & $-1.51 * * *$ & $-1.04 * * *$ \\
\hline & $(0.14)$ & $(0.16)$ & $(0.14)$ \\
\hline & {$[0.14]$} & {$[0.16]$} & {$[0.14]$} \\
\hline $\mathrm{R}^{2}$ & 0.12 & 0.21 & 0.12 \\
\hline Adjusted $\mathrm{R}^{2}$ & 0.12 & 0.16 & 0.12 \\
\hline Periods & 24 & 24 & 24 \\
\hline Countries & 97 & 97 & 97 \\
\hline Observations & 1653 & 1653 & 1653 \\
\hline
\end{tabular}

Note: Standard errors are presented below the corresponding coefficients in brackets. The asterisks $* * *, * *$, and $*$ indicate the significance at the $1 \%, 5 \%$, and $10 \%$ level, respectively. Cluster standard errors are presented in square brackets for robustness. 
Table 2: Determinants of the external debt (commodity-exporting and importing countries)

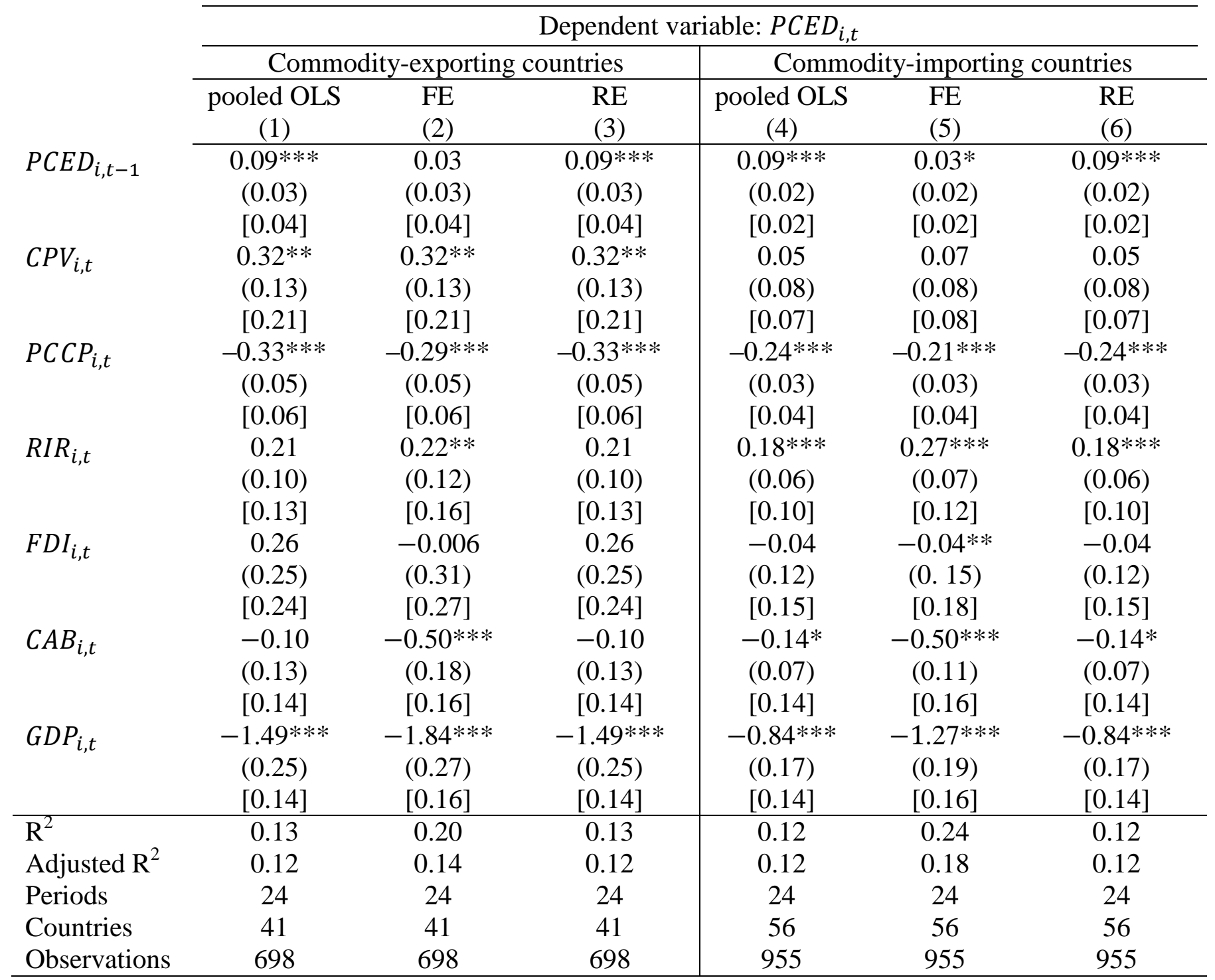

Note: Standard errors are presented below the corresponding coefficients in brackets. The asterisks $* * *, * *$, and * indicate the significance at the $1 \%, 5 \%$, and $10 \%$ level, respectively. Cluster standard errors are presented in square brackets. 
Table 3: Determinants of the external debt in the full sample (based on exchange rate regimes)

\begin{tabular}{|c|c|c|c|}
\hline \multirow{5}{*}{$P C E D_{i, t-1}$} & \multicolumn{3}{|c|}{ Dependent variable: $P C E D_{i, t}$} \\
\hline & $\begin{array}{l}\text { Fixed exchange rate } \\
\text { (1) }\end{array}$ & $\begin{array}{l}\text { Managed floating exchange rate } \\
\text { (2) }\end{array}$ & $\begin{array}{l}\text { Floating exchange rate } \\
\text { (3) }\end{array}$ \\
\hline & $-0.13^{* *}$ & 0.05 & 0.02 \\
\hline & $(0.06)$ & $(0.03)$ & $(0.04)$ \\
\hline & {$[0.05]$} & {$[0.03]$} & {$[0.03]$} \\
\hline \multirow[t]{3}{*}{$C P V_{i, t}$} & $0.34 *$ & $0.32 * * *$ & -0.06 \\
\hline & $(0.19)$ & $(0.09)$ & $(0.47)$ \\
\hline & {$[0.43]$} & {$[0.10]$} & {$[0.33]$} \\
\hline \multirow{3}{*}{$P C C P_{i, t}$} & $-0.25 * * *$ & $-0.32 * * *$ & -0.06 \\
\hline & $(0.09)$ & $(0.05)$ & $(0.20)$ \\
\hline & {$[0.08]$} & {$[0.08]$} & {$[0.20]$} \\
\hline \multirow{3}{*}{$R I R_{i, t}$} & 0.08 & $0.39 * * *$ & 0.21 \\
\hline & $(0.23)$ & $(0.11)$ & $(0.21)$ \\
\hline & {$[0.16]$} & {$[0.15]$} & {$[0.29]$} \\
\hline \multirow[t]{3}{*}{$F D I_{i, t}$} & -0.39 & -0.35 & -0.18 \\
\hline & $(0.39)$ & $(0.26)$ & $(1.01)$ \\
\hline & {$[0.31]$} & {$[0.31]$} & [0.89] \\
\hline \multirow[t]{3}{*}{$C A B_{i, t}$} & $-0.56 * *$ & $-0.68 * * *$ & 0.59 \\
\hline & $(0.22)$ & $(0.17)$ & $(0.72)$ \\
\hline & {$[0.16]$} & {$[0.24]$} & {$[0.54]$} \\
\hline \multirow{3}{*}{$G D P_{i, t}$} & -0.34 & $-1.42 * * *$ & $-2.00 * *$ \\
\hline & $(0.45)$ & $(0.25)$ & $(0.86)$ \\
\hline & {$[0.35]$} & {$[0.38]$} & [1.16] \\
\hline $\mathrm{R}^{2}$ & 0.20 & 0.28 & 0.71 \\
\hline Adjusted $\mathrm{R}^{2}$ & 0.08 & 0.20 & 0.56 \\
\hline Periods & 18 & 18 & 18 \\
\hline Countries & 31 & 67 & 27 \\
\hline Observations & 281 & 743 & 100 \\
\hline
\end{tabular}

Note: Standard errors are presented below the corresponding coefficients in brackets. The asterisks $* * *, * *$, and * indicate the significance at the $1 \%, 5 \%$, and $10 \%$ level, respectively. Cluster standard errors are presented in square brackets. 
Table 4: Determinants of external debt in commodity-exporting countries

\begin{tabular}{|c|c|c|c|}
\hline \multirow{5}{*}{$P C E D_{i, t-1}$} & \multicolumn{3}{|c|}{ Dependent variable: $P C E D_{i, t}$} \\
\hline & $\begin{array}{l}\text { Fixed exchange rate } \\
(1)\end{array}$ & $\begin{array}{l}\text { Managed floating exchange rate } \\
\text { (2) }\end{array}$ & $\begin{array}{l}\text { Floating exchange rate } \\
(3)\end{array}$ \\
\hline & -0.10 & 0.06 & -0.32 \\
\hline & $(0.10)$ & $(0.04)$ & $(0.25)$ \\
\hline & {$[0.09]$} & {$[0.05]$} & {$[0.30]$} \\
\hline \multirow[t]{3}{*}{$C P V_{i, t}$} & $1.21 * *$ & $0.37 * *$ & 3.10 \\
\hline & $(0.46)$ & $(0.15)$ & $(2.85)$ \\
\hline & {$[1.25]$} & {$[0.15]$} & {$[0.86]$} \\
\hline \multirow{3}{*}{$P C C P_{i, t}$} & $-0.41 *$ & $-0.30 * * *$ & -0.28 \\
\hline & $(0.23)$ & $(0.08)$ & $(0.56)$ \\
\hline & {$[0.09]$} & {$[0.09]$} & {$[0.46]$} \\
\hline \multirow[t]{3}{*}{$R I R_{i, t}$} & -0.09 & $0.33 * * *$ & -0.23 \\
\hline & $(0.38)$ & $(0.15)$ & $(0.60)$ \\
\hline & {$[0.34]$} & [0.19] & {$[0.32]$} \\
\hline \multirow{3}{*}{$F D I_{i, t}$} & -0.08 & -0.27 & -5.35 \\
\hline & $(0.96)$ & $(0.55)$ & $(5.36)$ \\
\hline & {$[0.75]$} & {$[0.45]$} & {$[4.51]$} \\
\hline \multirow{3}{*}{$C A B_{i, t}$} & $-0.86^{*}$ & $-0.86 * * *$ & 1.10 \\
\hline & $(0.45)$ & $(0.28)$ & $(1.31)$ \\
\hline & {$[0.28]$} & {$[0.53]$} & {$[0.64]$} \\
\hline \multirow[t]{3}{*}{$G D P_{i, t}$} & 0.36 & $-1.89 * * *$ & $-3.50 * *$ \\
\hline & $(0.95)$ & $(0.40)$ & $(1.38)$ \\
\hline & {$[0.66]$} & {$[0.78]$} & {$[1.86]$} \\
\hline $\mathrm{R}^{2}$ & 0.24 & 0.27 & 0.90 \\
\hline Adjusted $\mathrm{R}^{2}$ & 0.07 & 0.19 & 0.74 \\
\hline Periods & 18 & 18 & 15 \\
\hline Countries & 14 & 30 & 12 \\
\hline Observations & 111 & 350 & 30 \\
\hline
\end{tabular}

Note: Standard errors are presented below the corresponding coefficients in brackets. The asterisks $* * *, * *$, and * indicate the significance at the $1 \%, 5 \%$, and $10 \%$ level, respectively. Cluster standard errors are presented in square brackets. 
Table 5: Determinants of external debt in commodity-importing countries

\begin{tabular}{|c|c|c|c|}
\hline \multirow{5}{*}{$P C E D_{i, t-1}$} & \multicolumn{3}{|c|}{ Dependent variable: $P C E D_{i, t}$} \\
\hline & $\begin{array}{l}\text { Fixed exchange rate } \\
\text { (1) }\end{array}$ & $\begin{array}{l}\text { Managed floating exchange rate } \\
\text { (2) }\end{array}$ & $\begin{array}{l}\text { Floating exchange rate } \\
\text { (3) }\end{array}$ \\
\hline & $-0.28 * * *$ & 0.04 & 0.06 \\
\hline & $(0.07)$ & $(0.04)$ & $(0.05)$ \\
\hline & {$[0.10]$} & {$[0.06]$} & {$[0.18]$} \\
\hline \multirow{3}{*}{$C P V_{i, t}$} & -0.09 & $0.30 * *$ & -0.28 \\
\hline & $(0.15)$ & $(0.13)$ & $(0.48)$ \\
\hline & {$[0.15]$} & {$[0.15]$} & {$[0.95]$} \\
\hline \multirow[t]{3}{*}{$P C C P_{i, t}$} & -0.12 & $-0.34 * * *$ & 0.03 \\
\hline & $(0.07)$ & $(0.07)$ & $(0.22)$ \\
\hline & {$[0.08]$} & {$[0.06]$} & {$[0.31]$} \\
\hline \multirow{3}{*}{$R I R_{i, t}$} & $0.58 *$ & $0.45^{* *}$ & 0.15 \\
\hline & $(0.30)$ & $(0.17)$ & $(0.22)$ \\
\hline & {$[0.18]$} & {$[0.16]$} & {$[0.14]$} \\
\hline \multirow[t]{3}{*}{$F D I_{i, t}$} & -0.17 & -0.31 & -0.41 \\
\hline & $(0.32)$ & $(0.31)$ & $(1.05)$ \\
\hline & {$[0.29]$} & {$[0.33]$} & {$[2.01]$} \\
\hline \multirow[t]{3}{*}{$C A B_{i, t}$} & -0.32 & $-0.58 * * *$ & -0.90 \\
\hline & $(0.20)$ & $(0.22)$ & $(1.41)$ \\
\hline & {$[0.21]$} & {$[0.25]$} & [1.87] \\
\hline \multirow{3}{*}{$G D P_{i, t}$} & -0.59 & $-1.08 * * *$ & -0.66 \\
\hline & $(0.38)$ & $(0.33)$ & $(1.35)$ \\
\hline & {$[0.35]$} & {$[0.35]$} & [1.35] \\
\hline $\mathrm{R}^{2}$ & 0.31 & 0.28 & 0.50 \\
\hline Adjusted $\mathrm{R}^{2}$ & 0.20 & 0.19 & 0.19 \\
\hline Periods & 18 & 18 & 18 \\
\hline Countries & 17 & 37 & 15 \\
\hline Observations & 170 & 393 & 70 \\
\hline
\end{tabular}

Note: Standard errors are presented below the corresponding coefficients in brackets. The asterisks $* * *, * *$, and * indicate the significance at the $1 \%, 5 \%$, and $10 \%$ level, respectively. Cluster standard errors are presented in square brackets. 
Table 6: Determinants of external debt with the system-GMM method

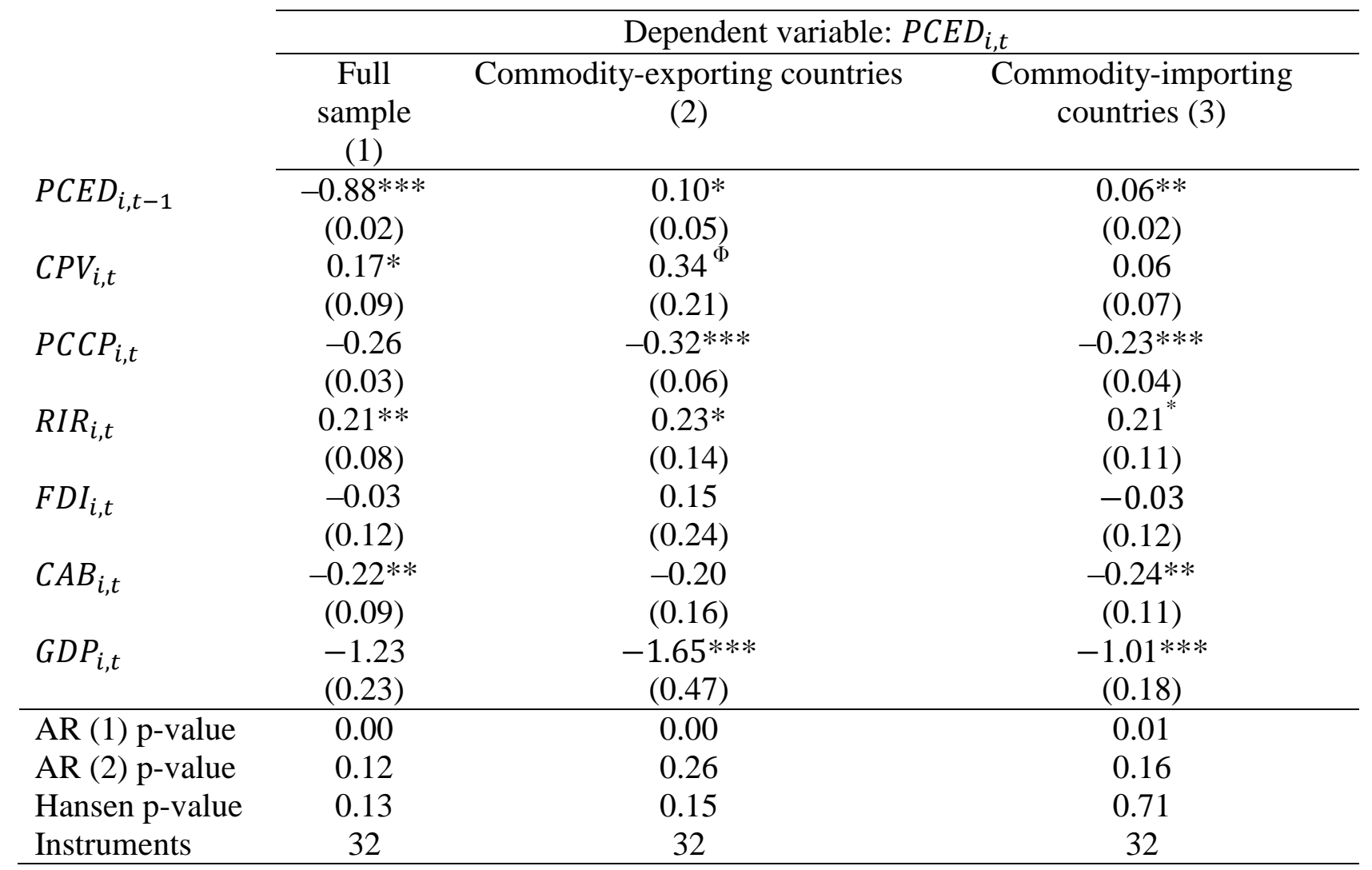

Note: Standard errors are presented below the corresponding coefficients in brackets. The asterisks ***, **, and $*$ indicate the significance at the $1 \%, 5 \%$, and $10 \%$ level, respectively. ${ }^{\Phi}$ indicates the significance at the $20 \%$ level.

Figure 1: Movement of commodity price volatility and external debt

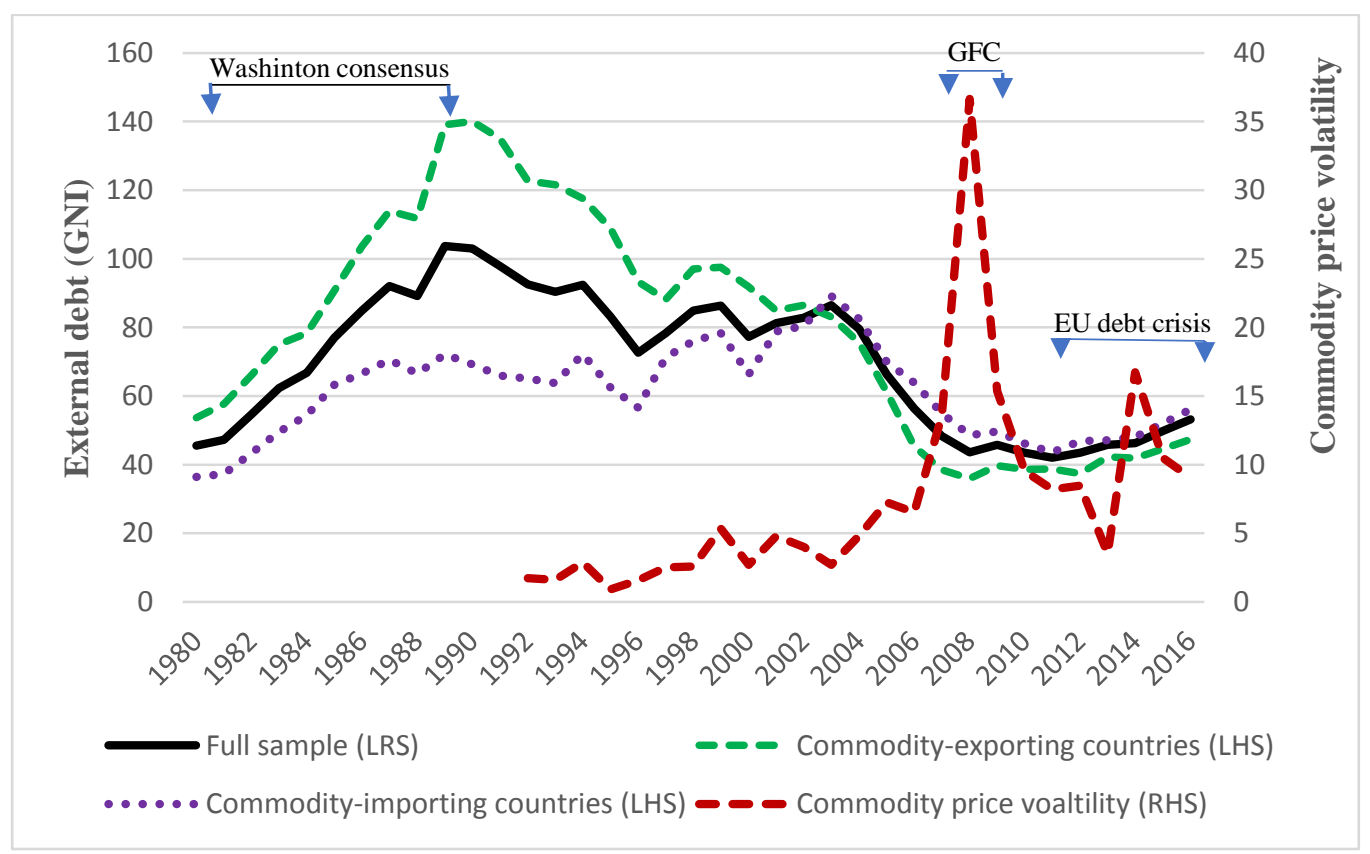

Source: Author's calculation based on WB (2018) and IMF (2018) data. 
Figure 2a. Shocks with floating exchange rate

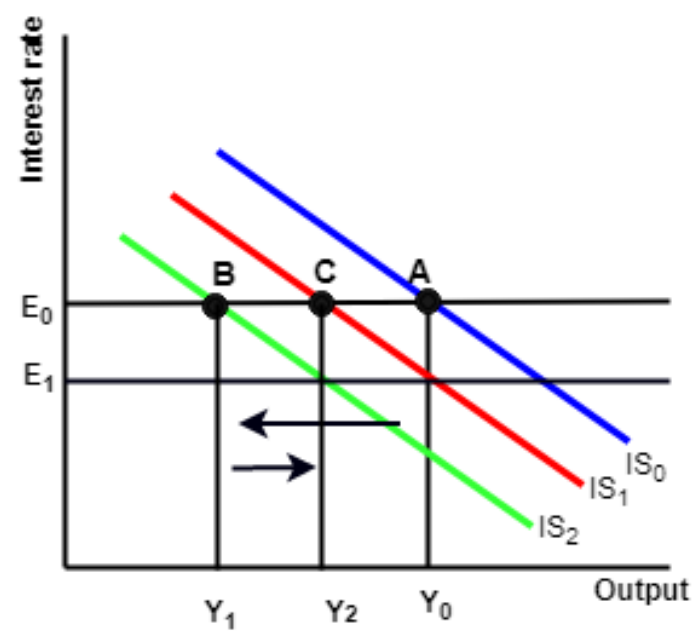

Figure 2b. Shocks with fixed exchange rate

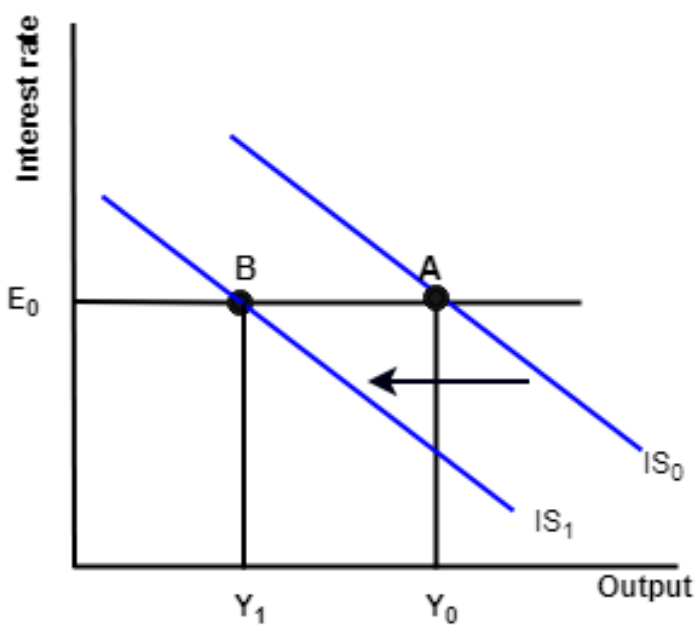

Figure 3: Commodity price volatility and external debt

a. Under a floating exchange rate regime

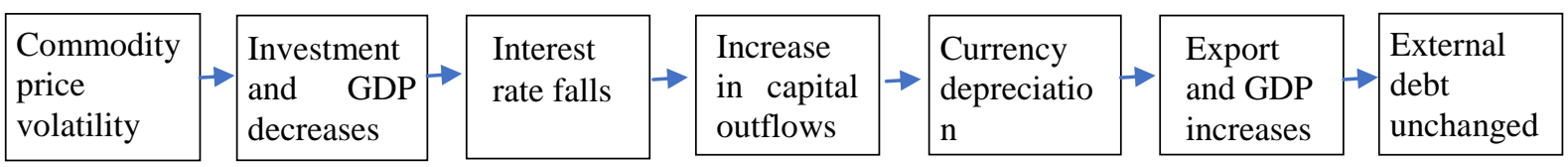

b. Under a fixed exchange rate regime

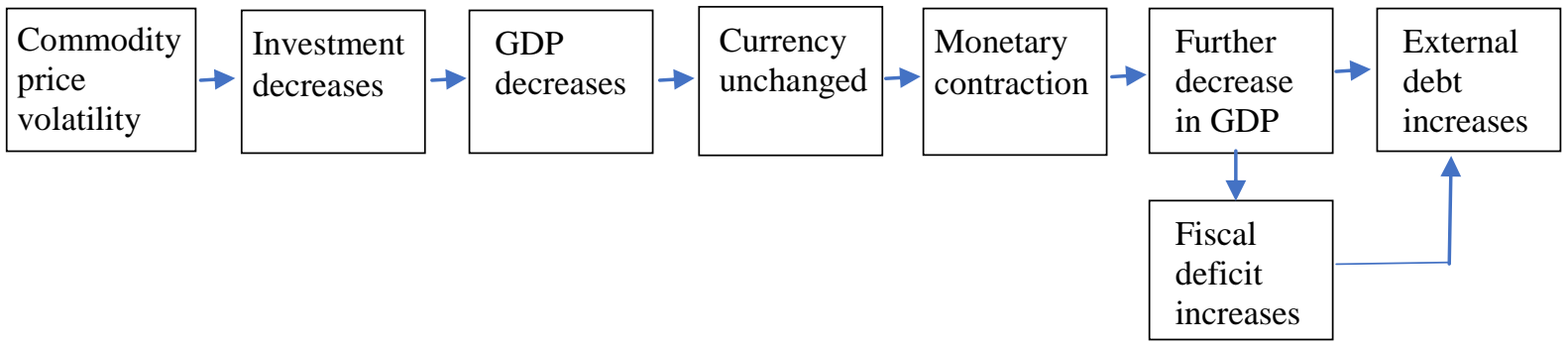




\section{Appendix A}

Table A 1: List of countries $(n=97)$

\begin{tabular}{llll}
\hline Afghanistan & Congo, Rep. & Liberia & Rwanda \\
Albania & Costa Rica & Macedonia, North & Samoa \\
Angola & Cote d'Ivoire & Malawi & Sao Tome \\
Argentina & Dominica & Malaysia & Senegal \\
Armenia & Dominican Republic & Maldives & Sierra Leone \\
Azerbaijan & Egypt, Arab Rep. & Mali & Solomon Islands \\
Bangladesh & El Salvador & Mauritius & South Africa \\
Belarus & Fiji & Mexico & Sri Lanka \\
Belize & Gabon & Moldova & St. Lucia \\
Benin & The Gambia & Mongolia & St. Vincent \\
Bhutan & Georgia & Montenegro & Syrian Arab Rep. \\
Bolivia & Grenada & Morocco & Tajikistan \\
Bosnia and Herzegovina a & Guatemala & Mozambique & Tanzania \\
Botswana & Guinea-Bissau & Myanmar & Thailand \\
Brazil & Guyana & Nepal & Togo \\
Burkina Faso & Haiti & Nicaragua & Tonga \\
Burundi & Honduras & Nigeria & Uganda \\
Cabo Verde & India & Pakistan & Ukraine \\
Cameroon & Indonesia & Panama & Vanuatu \\
Central African Rep. & Jamaica & Papua New Guinea & Venezuela \\
Chad & Jordan & Paraguay & Vietnam \\
China & Kenya & Peru & Zambia \\
Colombia & Kyrgyz Republic & Philippines & \\
Comoros & Lebanon & Romania & \\
Congo, Dem. & Lesotho & Russian Federation & \\
\hline
\end{tabular}


Table A 2: List of commodity-exporting and commodity-importing countries

\begin{tabular}{ll|ll}
\hline \multicolumn{2}{l|}{ Commodity-exporting } & Countries $(\mathrm{n}=41)$ & Commodity-importing countries $(\mathrm{n}=56)$ \\
\hline Argentina & Paraguay & Afghanistan & Lesotho \\
Armenia & Peru & Albania & Liberia \\
Benin & Russia & Angola & Macedonia, North \\
Bolivia & Rwanda & Azerbaijan & Malaysia \\
Botswana & Senegal & Bangladesh & Maldives \\
Burundi & Sierra & Belarus & Mauritius \\
Cameroon & Syria & Belize & Mexico \\
Central African Rep. & Tajikistan & Bhutan & Mongolia \\
Colombia & Tanzania & Bosnia & Montenegro \\
Congo, Rep. & Togo & Brazil & Morocco \\
Cote d'Ivoire & Uganda & Burkina Faso & Myanmar \\
Egypt & Venezuela & Cabo Verde & Nepal \\
Fiji & Zambia & Chad & Nigeria \\
Gabon & & China & Pakistan \\
The Gambia & Comoros & Philippines \\
Guatemala & Congo, Dem. & Romania \\
Guyana & & Costa Rica & Samoa \\
Honduras & Dominica & Sao Tome \\
Indonesia & & Dominican Rep. & Solomon Islands \\
Kenya & & El Salvador & South Africa \\
Kyrgyz Republic & & Georgia & Sri Lanka \\
Malawi & & Grenada & St. Lucia \\
Mali & & Guinea-Bissau & St. Vincent \\
Moldova & Haiti & Thailand \\
Mozambique & & India & Tonga \\
Nicaragua & & Jamaica & Ukraine \\
Panama & & Jordan & Vanuatu \\
Papua New Guinea & & & Vietnam \\
\hline & & & \\
\hline
\end{tabular}


Table A 3: Description of the variables

\begin{tabular}{|c|c|c|c|}
\hline Variables & Mnemonic & Description & Source \\
\hline \multicolumn{4}{|l|}{ Dependent variable } \\
\hline $\begin{array}{l}\text { External debt }(\% \text { of } \\
\text { GNI) }\end{array}$ & $E D_{i, t}$ & $\begin{array}{l}\text { Total external debt stocks to gross national income } \\
\text { is a debt owed to non-residents repayable in } \\
\text { currency, goods, or services. }\end{array}$ & WDI, WB \\
\hline \multicolumn{4}{|l|}{ Control variables } \\
\hline Commodity prices & $C P_{i, t}$ & $\begin{array}{l}\text { All commodity price index using } 2005=100 \text {, } \\
\text { includes both fuel and non-fuel price indices. }\end{array}$ & $\begin{array}{l}\text { Commodity } \\
\text { data portal, } \\
\text { IMF }\end{array}$ \\
\hline $\begin{array}{l}\text { Commodity price } \\
\text { volatility }\end{array}$ & $C P V_{i, t}$ & Use standard deviation to estimate volatility. & $\begin{array}{l}\text { Author's } \\
\text { calculation }\end{array}$ \\
\hline Real interest rate $(\%)$ & $R I R_{i, t}$ & $\begin{array}{l}\text { The real interest rate is the lending interest rate } \\
\text { adjusted for inflation as measured by the GDP } \\
\text { deflator. }\end{array}$ & WDI, WB \\
\hline $\begin{array}{l}\text { Foreign direct } \\
\text { investment, net } \\
\text { inflows (\% of GDP) }\end{array}$ & $F D I_{i, t}$ & $\begin{array}{l}\text { Foreign direct investment is the net inflows of } \\
\text { investment to acquire a lasting management interest } \\
\text { in an enterprise operating in an economy. }\end{array}$ & WDI, WB \\
\hline $\begin{array}{l}\text { Current account } \\
\text { balance (\% of GDP) }\end{array}$ & $C A B_{i, t}$ & $\begin{array}{l}\text { The current account balance is the sum of net } \\
\text { exports of goods and services, net primary income, } \\
\text { and net secondary income. }\end{array}$ & WDI, WB \\
\hline $\begin{array}{l}\text { GDP per capita } \\
\text { growth (annual \%) }\end{array}$ & $G D P_{i, t}$ & $\begin{array}{l}\text { Annual percentage growth rate of GDP per capita } \\
\text { based on constant local currency. Aggregates are } \\
\text { based on constant } 2010 \text { U.S. dollars. }\end{array}$ & WDI, WB \\
\hline \multicolumn{3}{|l|}{ Exchange rate regimes } & \multirow[b]{2}{*}{$\begin{array}{l}\text { Reinhart, } \\
\text { Ilzetzki \& } \\
\text { Rogoff } \\
\text { (2009). }\end{array}$} \\
\hline $\begin{array}{l}\text { Natural regime } \\
\text { classification }\end{array}$ & & $\begin{array}{l}\text { i. Fixed exchange rate regimes: No separate legal } \\
\text { tender, and currency board arrangements. Dummy } \\
\text { variable which takes the value of } 1 \text { if the country } \\
\text { uses fine classification } 1-2 \text { and } 0 \text { otherwise. } \\
\text { ii. Managed floating regimes: Limited flexibility } \\
\text { regimes Dummy variable which takes the value of } 1 \\
\text { if the country uses fine classification } 3-12 \text { and } 0 \\
\text { otherwise. } \\
\text { iii. Floating exchange rate regimes: Freely } \\
\text { floating, and freely falling. Dummy variable which } \\
\text { takes the value of } 1 \text { if the country uses fine } \\
\text { classification } 13-15 \text { and } 0 \text { otherwise. }\end{array}$ & \\
\hline
\end{tabular}

Note: To ensure stationarity, we use percentage change in external debt and commodity price series and they expressed as $P C E D_{i, t}$ and $P C C P_{i, t}$ respectively in equation (1).

Change in external debt $\left(\boldsymbol{P C E D _ { i , t }}\right)$ : Change in external debt is our dependent variable and is denoted by $P C E D_{i, t}$ in the model. We use debt as a measure of fiscal policy because it is a broader measurement of government fiscal activities than the budget deficit. The commonly reported measures of financial balance overstate the economically relevant 
deficit by including the inflation component of interest payments on the government debt. It would be more appropriate, however, if the interest component of government debt were treated as a type of debt repayment rather than as an item of current budgetary expenditure. The change in government debt automatically adjusts this component (Roubini \& Sachs 1989).

Lagged change in external debt $\left(P C E D_{i, t-1}\right):$ We include the lagged value of external debt as an influencing variable to correct for past budgetary imbalances. A significant change in fiscal policy in the past may induce governments to undo part of the recent increases. Changes in the government debt may also result from lags or delays in effecting budgetary initiatives, for example, previous fiscal policy decisions, such as the implementation of tax reforms and significant spending reforms, can affect public finances in the following years.

Change in commodity prices $\left(\boldsymbol{P C C} \boldsymbol{P}_{i, t}\right)$ : It is expected that external debt will decrease with the increase in commodity prices and vice-versa. Governments can repay the debt by using extra revenue accrued from the commodity price windfall, especially in the commodity-exporting countries. The commodity importing country's government debt is also influenced by commodity prices through import tax. In both groups of countries, government external debt will decrease with the increase in commodity prices.

Commodity price volatility $\left(\boldsymbol{C P} V_{i, t}\right)$ : Generally, primary commodity prices are more volatile than the prices of manufacturing goods. Following the recent global financial crisis (GFC) in 2007-2009, commodity price volatility increased, considerably (Omojolaibi \& Egwaikhide 2014). Because of this volatility, government revenue tends to be more volatile along with government spending. The uncertainty of future revenue from commodities and the variability of those revenues results in changes in the expenses as the government 
reassesses its expected revenue stream, generating significant adjustment costs. In these circumstances, governments try to borrow from external sources to smooth out the level of economic activities. As a result, it can generally be expected that commodity price volatility will increase government external debt.

Real interest rate $\left(\boldsymbol{R I} \boldsymbol{R}_{i, t}\right)$ : The interest rate is the price a borrower pays for the use of the money they borrow from a lender/financial institution or the fee paid on borrowed assets (Crowley 2007). It is expected that external debt increases with an increase in real interest rates because more money is needed to pay to the lenders.

Foreign direct investment $\left(\boldsymbol{F D I} I_{i, t}\right):$ It is expected that an increase in FDI rate promotes economic growth that helps to reduce external debt accumulation. According to Borensztein, De Gregorio and Lee (1998), FDI is an important vehicle for the transfer of technologies, knowledge, and human capital, all associated with higher productivity and eventually decrease external debt.

Current account balance $\left(\boldsymbol{C A} \boldsymbol{B}_{i, t}\right)$ : It is expected that the current account balance has a negative impact on external debt accumulation. If a country's balance increases, indicating that its exports are more than imports. This encourages investment and output growth causing lower external debt and vice-versa. Mehta and Kayumi (2014) show there is a negative relationship between current account balance and external debt in India.

Gross domestic product $\left(\boldsymbol{G D P} \boldsymbol{P}_{\boldsymbol{i}, t}\right)$ : It is expected that external debt decreases with the increase in GDP per capita. This is because with the higher per capita income, people will pay more taxes which increase the government's tax revenue and also decreases the government's expenses in the form of social benefits. 
Table A4: Descriptive statistics

\begin{tabular}{lccccccccc} 
& $E D_{i, t}$ & $P C E D_{i, t}$ & $C P V_{i, t}$ & $C P_{i, t}$ & $P C C P_{i, t}$ & $R I R_{i, t}$ & $F D I_{i, t}$ & $C A B_{i, t}$ & $G D P_{i, t}$ \\
\cline { 2 - 9 } Mean & 61.02 & 0.92 & 8.50 & 111.68 & 4.73 & 7.38 & 4.82 & -5.46 & 2.69 \\
Median & 43.71 & -1.44 & 6.51 & 111.25 & 4.52 & 7.17 & 3.26 & -4.31 & 2.62 \\
Maximum & 1252.42 & 300.07 & 36.65 & 192.57 & 27.80 & 77.61 & 84.94 & 43.39 & 33.03 \\
Minimum & 3.89 & -80.42 & 0.91 & 47.72 & -35.27 & -98.15 & -37.16 & -80.05 & -22.55 \\
Std. Dev. & 72.11 & 25.19 & 7.82 & 50.16 & 18.19 & 11.26 & 6.26 & 10.20 & 4.25 \\
Skewness & 7.52 & 3.90 & 2.29 & 0.26 & -0.50 & -1.29 & 3.73 & -0.95 & 0.20 \\
Kurtosis & 93.02 & 39.26 & 8.70 & 1.58 & 2.47 & 18.04 & 31.87 & 7.90 & 9.00 \\
Observations & 1660 & 1660 & 1660 & 1660 & 1660 & 1660 & 1660 & 1660 & 1660 \\
\hline
\end{tabular}

Table A5: Unit root test

\begin{tabular}{|c|c|c|c|c|}
\hline & \multicolumn{2}{|c|}{ Augmented Ducky-Fuller (ADF) } & \multicolumn{2}{|c|}{ Phillips-Peron (PP) } \\
\hline & Statistics & p-value & Statistics & P-value \\
\hline$E D_{i, t}$ & 196.06 & 0.44 & 214.00 & 0.15 \\
\hline$P C E D_{i, t}$ & 850.77 & 0.00 & 2898.31 & 0.00 \\
\hline$C P V_{i, t}$ & 336.65 & 0.00 & 493.34 & 0.00 \\
\hline$C P_{i, t}$ & 101.60 & 1.00 & 92.71 & 1.00 \\
\hline$P C C P_{i, t}$ & 460.99 & 0.00 & 980.37 & 0.00 \\
\hline$R I R_{i, t}$ & 576.98 & 0.00 & 1063.64 & 0.00 \\
\hline$F D I_{i, t}$ & 387.56 & 0.00 & 524.20 & 0.00 \\
\hline$C A B_{i, t}$ & 383.38 & 0.00 & 391.70 & 0.00 \\
\hline$G D P_{i, t}$ & 962.23 & 0.00 & 1076.96 & 0.00 \\
\hline
\end{tabular}

Table A6: Results of the Hausman test

\begin{tabular}{|c|c|c|c|}
\hline \multicolumn{4}{|c|}{ Null hypothesis: RE model is appropriate } \\
\hline Country groups & Chi-Sq. Statistics & $p$-value & Comments \\
\hline Full Sample & 149.29 & 0.00 & Reject Null hypothesis \\
\hline $\begin{array}{l}\text { Commodity-exporting } \\
\text { countries }\end{array}$ & 49.84 & 0.00 & Reject Null hypothesis \\
\hline $\begin{array}{l}\text { Commodity-importing } \\
\text { countries }\end{array}$ & 103.11 & 0.00 & Reject Null hypothesis \\
\hline
\end{tabular}




\section{$\underline{\text { Appendix B }}$}

\section{A 2.1. Pooled OLS model}

In the pooled OLS models, we have pooled all the observations in OLS regression meaning that implicitly we assume the coefficient is the same for all the individuals. So, we can write the model (1) by the following form -

$$
\begin{array}{r}
P C E D_{i, t}=\beta_{0}+\beta_{1} P C E D_{i, t-1}+\beta_{2} C P V_{i, t}+\beta_{3} P C C P_{i, t}+\beta_{4} R I R_{i, t}+\beta_{5} F D I_{i, t}+\beta_{6} C A B_{i, t} \\
+ \\
\beta_{7} G D P_{i, t}+\varepsilon_{i, t}
\end{array}
$$

(3)

\section{A 2.2. Random effect (RE) models}

In the RE, the variation across entities is assumed to be random and uncorrelated with the independent variables included in the model. The rationale behind the random effect models is that, unlike the fixed effect models, the variation across entities is assumed to be random and uncorrelated with the predictor or independent variables included in the model. The random-effects model includes all fixed effect assumptions plus the additional requirement that $\left(Q_{i}\right)$ is independent of all explanatory variables in all periods. Hence, the variability of the constant for each section comes from:

$$
\beta_{0 i}=\beta_{0}+Q_{i}
$$

Where $Q_{i}$ is a zero-mean standard random variable. Therefore equation (3) with random effects takes the following form- 
$P C E D_{i, t}=\beta_{0}+\beta_{1} P C E D_{i, t-1}+\beta_{2} C P V_{i, t}+\beta_{3} P C C P_{i, t}+\beta_{4} R I R_{i, t}+\beta_{5} F D I_{i, t}+\beta_{6} C A B_{i, t}+$ $\mathrm{Q}_{i}+\beta_{7} G D P_{i, t}+\varepsilon_{i, t}$

(5)

We estimate equation (3) and (5) for all country groups mentioned above. 